\title{
PENGARUH MODEL DISCOVERY LEARNING BERBANTUAN MEDIA AUDIOVISUAL TERHADAP KETERAMPILAN MENULIS TEKS PROSEDUR SISWA KELAS VII SMP NEGERI 12 PADANG
}

\author{
Oleh: \\ Maretta Arviyana, Syahrul, Tressyalina \\ Pendidikan Bahasa dan Sastra Indonesia \\ FBS Universitas Negeri Padang \\ e-mail: marettaarvyana@yahoo.co.id
}

\begin{abstract}
The purpose of this study were (1) to describe the skills of writing the text of the procedures of the students of class VII of SMP Negeri 12 Padang without using the audiovisual media aided discovery learning model. (2) to describe the skills of writing the text of the procedure of class VII students of SMP Negeri 12 Padang by using discovery learning model audiovisual media. (3) to analyze the effect of audiovisual media aided discovery learning model to the writing skills skill of class VII students of SMP Negeri 12 Padang. Based on data analysis, the use of audiovisual media-aided discovery learning model influences the writing skills skill of class VII students of SMP Negeri 12 Padang.
\end{abstract}

Kata Kunci: pengaruh, discovery learning, media audiovisual, menulis teks prosedur

\section{A. Pendahuluan}

Berdasarkan hasil penelitian Programme for International Student Assessment kondisi literasi bangsa Indonesia berada pada urutan 64 dari 65 negara. Tingkat membaca siswa bangsa Indonesia berada pada urutan 57 dari 65 negara. Hal ini membuktikan bahwa kemampuan membaca dan menulis bangsa Indonesia sangat rendah. Literasi bukanlah sekedar keterampilan membaca dan menulis secara mekanis. Literasi merupakan jantung kemampuan siswa untuk belajar membaca dan menulis dari berbagai sumber buku yang dibaca oleh siswa. Budaya literasi masyarakat Indonesia masih sangat rendah, salah satu penyebabnya birokrat pendidikan tidak paham tentang literasi itu sendiri. Akibatnya, literasi tidak menjadi bagian dari kurikulum, termasuk dalam Kurikulum 2013. Salah satu literasi yang berpengaruh terhadap kemampuan siswa adalah keterampilan menulis.

Menulis merupakan salah satu keterampilan berbahasa yang berarti mengubah bunyi bahasa menjadi lambang bunyi. Lambang bunyi kemudian dirangkai menjadi kata dan kata dirangkai menjadi kalimat hingga akhirnya terbentuk wacana bahasa tulis. Siswa dituntut terampil memanfaatkan struktur bahasa di dalam kegiatan menulis agar tulisan yang dihasilkan menarik untuk dibaca.

Keterampilan menulis memiliki peranan penting dalam kehidupan manusia. Keterampilan ini merupakan kegiatan yang produktif dan ekspresif sehingga keterampilan ini tidak datamg dengan sendirinya tetapi membutuhkan latihan dan kebiasaan yang berkesinambungan. Keterampilan menulis dikatakan produktif karena keterampilan tersebut terbentuk dari proses terintegrasinya apa yang telah didengar, dibicarakan dan dibaca, kemudian di ekspresikan kembali dalam bentuk tulisan. Seseorang yang memiliki keterampilan menulis dapat mengungkapkan pikiran dan gagasannya untuk mencapai maksud dan tujuan tertentu. Gagasan itu dapat berupa fakta, pengalaman, pengamatan, penelitian, pemikiran atau analisis suatu masalah. Salah satu keterampilan menulis yang terdapat pada kurikulum 2013 
revisi 2016 di kelas VII Sekolah Menengah Pertama (SMP) adalah keterampilan menulis teks prosedur.

As'Adah (2016) berdasarkan prinsip pembelajaran Bahasa Indonesia dalam Kurikulum 2013, siswa dituntut mampu memproduksi atau menulis teks dengan baik dan benar. Sejalan dengan hal tersebut, arah pembelajaran keterampilan menulis di SMP berdasarkan Kurikulum 2013 lebih dititikberatkan pada tingkat kreatifitas siswa dalam mengembangkan ide dan gagasanya. Teks prosedur merupakan suatu langkah-langkah dan tujuan yang harus diikuti agar suatu pekerjaan dapat dilakukan. Teks prosedur memiliki manfaat yang besar dalam kehidupan. Teks prosedur membantu mengetahui cara-cara melakukan aktifitas tertentu dan kebiasaan hidup yang benar. Selain itu, membantu dalam menggunakan alat dengan benar tanpa membahayakan diri dan tanpa merusak alat itu sendiri. Untuk mencapai tujuan yang tepat teks prosedur harus disusun sesuai dengan urutan yang benar. Karena langkah-langkah dalam menyusun teks prosedur tidak dapat dibalik-balik untuk mencapai tujuan tersebut.

Pradana (2013) mengatakan bahwa pelajaran menulis teks prosedur menjadi penting karena setiap peserta didik mampu memahami dan mengutarakan idenya. Apabila ide tersebut diutarakan secara sistematis dan terperinci pelajaran bahasa Indonesia di sekolah-sekolah yang memasukkan teks prosedur sebagai salah satu materi yang dianggap penting dapat dipahami oleh siswa. Namun, beberapa sekolah di Gianyar belum bisa membaca fenomena tersebut sehingga ketercapaian pemahaman siswa tentang materi teks prosedur masih rendah. Hal tersebut berdampak negatif bagi siswa. Siswa kurang mampu menyampaikan atau mengutarakan ide pikirannya secara baik dan benar. Peneliti menemukan masalah tersebut di Sekolah Menengah Atas Dwijendra Gianyar. Dari hasil wawancara dengan salah satu guru bahasa Indonesia Wayan Suarta, beliau mengatakan "dalam masalah menulis memang anakanak kurang apalagi menulis teks prosedur, mereka jadi kurang berani dan kurang bisa menyampaikan masalah atau unek-unek mereka.

Berdasarkan hasil wawancara penulis dengan guru mata pelajaran Bahasa Indonesia kelas VII SMP Negeri 12 Padang, H. Amril, S.Pd. pada tanggal 20 September 2016. Diketahui bahwa hasil rata-rata ulangan harian menulis teks prosedur belum maksimal dan belum mencapai Kriteria Ketuntasan Minimal (KKM). Nilai rata-rata yang diperoleh siswa yaitu 70.00, sedangkan KKM yang ditetapkan yaitu 80,00.

Alasan dipilihnya SMP Negeri 12 Padang sebagai tempat penelitian adalah sebagai berikut. Pertama, SMP Negeri 12 Padang merupakan tempat peneliti melaksanakan kegiatan PLK, sehingga proses belajar mengajar yang dilakukan di sekolah tersebut diketahui dengan baik. Kedua, keterampilan menulis teks prosedur siswa masih rendah, sehingga diperlukan model pembelajaran yang tepat dan menarik untuk mempermudah siswa menulis teks prosedur. Ketiga, di sekolah ini belum pernah diterapkan model discovery learning berbantuan media audiovisual dalam pembelajaran menulis teks prosedur.

Model Pembelajaran yang dimaksud adalah model pembelajaran dengan menggunakan media pembelajaran yang efektif guna menunjang kegiatan pembelajaran. Model pembelajaran dan media pembelajaran yang beraneka ragam menyebabkan guru harus selektif. Salah satu faktor yang mempengaruhi penentuan model dan media pembelajaran adalah materi pembelajaran. Model dan media yang efektif untuk pengajaran materi satu belum tentu efektif untuk mengajarkan materi yang lain. Setiap materi mempunyai karakteristik yang menentukan media digunakan untuk materi tersebut. Model discovery learning adalah suatu model pembelajaran yang mengharuskan siswa menemukan dan mencari suatu konsep atau sesuatu prinsip yang sebelumnya tidak diketahui.

Tumurun (2016) menggunakan model discoverylearning ini siswa akan mampu untukmengembangkan keterampilan berpikirkreatifnya. Hal ini dikarenakan model discovery learning memiliki tahapan-tahapan yang mampu untuk melatih siswa berpikir kreatif. Tahapantahapan tersebut di antaranya orientasi atau menemukan masalah, dan merumuskan masalah. Padatahapan ini siswa dilatih dua indikator berpikir kreatif yaitu lancar dan luwes. Kemudian dilakukan tahapan merencanakan pemecahan masalah melalui percobaan atau cara lain 
pembelajaran. Pada tahapan ini siswa dilatih memiliki salah satu indikator keterampilan berpikir kreatif yaitu berpikir orisinil. Setelah merencanakan pemecahan masalah siswa kemudian melakukan percobaan. Pada tahapan melakukan percobaan siswa dilatih untuk memiliki indikator berpikir kreatif yaitu berpikir elaboratif. Selanjutnya siswa melakukan analisis data yang terah mereka temukan. Pada tahapan ini siswa dilatih untuk berpikir lancar, luwes, dan elaboratif. Setelah melakukan analisis data siswa diminta untuk menyimpulkan hasil dari percobaan yang telah mereka buat.

Rosarina (2016) mengatakan bahwa Discovery learning merupakan suatu model pemecahan masalah yang akan bermanfaat bagi anak didik dalam menghadapi kehidupannya di kemudian hari. Penerapan model discovery learning ini bertujuan agar siswa mampu memahami materi perubahan wujud bendadengan sebaik mungkin dan pembelajaran lebih terasa bermakna, sehingga hasil belajarsiswa pun akan meningkat. Model discovery learning ini dalam prosesnya menggunakan kegiatan dan pengalaman langsung sehingga akan lebih menarik perhatian anak didik dan memungkinkan pembentukan konsep-konsep abstrak yang mempunyai makna, serta kegiatannya pun lebih realistis.

Model discovery learning pun banyak memberikan kesempatan bagi para anak didik untuk terlibat langsung dalam kegiatan belajar, kegiatan seperti itu akan lebih membangkitkan motivasi belajar, karena disesuaikan dengan minat dan kebutuhan mereka sendiri. Model discovery learning ini menitikberatkan pada kemampuan mental dan fisik para anak didik yang akan memperkuat semangat dan konsentrasi mereka dalam melakukan kegiatan pembelajaran. Ada pun tahapan model discovery learning, terdiri dari observasi untuk menemukan masalah, merumuskan masalah, mengajukan hipotesis, merencanakan pemecahan masalah melalui percobaan atau cara lain, melaksanakan pengamatan dan pengumpulan data, analisis data, dan menarik kesimpulan atas percobaan yang telah dilakukan atau penemuan.

Melalui modeldiscovery learning siswa menjadi lebih dekat dengan apa yang menjadi sumber belajarnya, rasa percaya diri siswa akan meningkat karena dia merasa apa yang telah dipahaminya ditemukan oleh dirinya sendiri, kerjasama dengan temannya pun akan meningkat, serta tentunya menambah pengalaman siswa.

Wirnani (2016) Model discovery learning memiliki karakteristik yang cocok untuk digunakan dalam mengajarkan materi ciri khas (karakteristik) dan klasifikasi, misalnya mengajarkan berbagai klasifikasi beberapa hewan. Karakterisitik dari model discovery learning yang lainnya adalah model pembelajaran yang berpusat kepada siswa (student centered) yang melatihkan kemandirian untuk meningkatkan keterampilan dan proses kognitif. Model tersebut melibatkan partisipasi aktif siswa untuk mengamati, merumuskan, menggolongkan, membuat dugaan, menjelaskan, serta menarik kesimpulan yang mendorong siswa menemukan konsep dan prinsip materi melalui proses mentalnya sendiri selama proses pembelajaran berlangsung.

Tujuan penelitian ini untuk mendeskripsikan hal-hal sebagai berikut. Pertama, mendeskripsikan keterampilan menulis teks prosedur siswa kelas VII SMP Negeri 12 Padang sebelum menggunakan model discovery learning berbantuan media audiovisual. Kedua, mendeskripsikan keterampilan menulis teks prosedur siswa kelas VII SMP Negeri 12 Padang sesudah menggunakan model discovery learning berbantuan media audiovisual. Ketiga, menganalisis pengaruh model discovery learning berbantuan media audiovisual terhadap keterampilan menulis teks prosedur siswa kelas VII SMP Negeri 12 Padang.

\section{B. Metode Penelitian}

Jenis penelitian ini adalah penelitian kuantitatif. Penelitian ini dikatakan penelitian kuantitatif dikarenakan penelitian ini berlandaskan pada filsafat positivisme yang digunakan untuk meneliti populasi dan sampel tertentu. Menurut Sugiyono (2010:15), penelitian kuantitatif adalah penelitian yang berlandaskan pada filsafat positivisme, digunakan untuk meneliti populasi atau sampel tertentu, pengumpulan data menggunakan instrumen penelitian, analisis data bersifat kuantitatif/statistik dengan tujuan untuk menguji hipotesis yang telah 
ditetapkan. Data penelitian yang diolah berupa angka-angka yang diperoleh dari hasil skor tes keterampilan menulis teks prosedur siswa kelas VII SMP Negeri 12 Padang.

Metode penelitian yang digunakan dalam penelitian ini adalah metode eksperimen. Menurut Arifin (2012:42), metode eksperimen merupakan metode yang sistematis guna membangun hubungan yang mengandung fenomena sebab-akibat. Dalam metode eksperimen penelitian harus melakukan tiga kegiatan sekaligus, yaitu mengontrol, memanipulasi dan observasi. Jenis eksperimen yang digunakan adalah eksperimen semu (quasi eksperimental). Selanjutnya, Arifin (2012:74) menyatakan tujuan eksperimen semu adalah memprediksi keadaan yang dapat dicapai melalui eksperimen yang sebenarnya, tetapi tidak ada pengontrolan atau manipulasi terhadap seluruh variabel yang relevan.

Rancangan atau desain penelitian yang digunakan dalam penelitian ini adalah rancangan statis dua kelompok, menurut Sudjana dan Ibrahim (2007:36), rancangan statistik dua kelompok merupakan rancangan penelitian yang menggunakan dua kelompok sampel yang dianggap sama dalam semua aspek yang relevan dan perbedaannya hanya terdapat pada perlakuan yang diberikan pada sekelompok eksperimen. Populasi dalam penelitian ini adalah seluruh siswa kelas VII SMP Negeri 12 Padang yang terdaftar pada tahun ajaran 2016-2017 yang berjumlah 268 orang yang tersebar dalam delapan kelas, yaitu kelas VII 1, VII 2, VII 3, VII 4, VII 5, VII 6, VII7, dan VII8

Sampel merupakan bagian populasi yang akan diteliti. Dikarenakan populasi penelitian lebih dari seratus siswa, maka perlu digunakan teknik pengambilan sampel. Pemilihan sampel penelitian yang dilakukan dengan teknik purposive sampling. Purposive sampling adalah suatu cara pengambilan sampel berdasarkan pada pertimbangan atau tujuan tertentu, serta berdasarkan ciri-ciri atau sifat-sifat tertentu yang sudah diketahui sebelumnya. Sampel penelitian ini diambil berdasarkan nilai rata-rata keterampilan menulis teks prosedur siswa kelas VII SMP Negeri 12 Padang. Pengambilan sampel dalam penelitian ini berdasarkan nilai rata-rata ulangan harian di bawah KKM yaitu 80 untuk menulis teks prosedur dari delapan kelas di VII SMP Negeri 12 Padang.

Sugiyono (2010:60) menjelaskan variabel penelitian adalah segala sesuatu yang berbentuk apa saja yang ditetapkan oleh peneliti unuk dipelajari sehingga diperoleh informasi tentang hal tersebut, kemudian ditarik kesimpulannya.

Variabel penelitian ini adalah keterampilan menulis teks prosedur sebelum dan sesudah menggunakan model discovery learning berbantuan media audiovisual siswa kelas VII SMP Negeri 12 Padang. Data penelitian ini adalah skor hasil tes keterampilan menulis teks prosedur siswa kelas VII SMP Negeri 12 Padang sebelum dan sesudah menggunakan model discovery learning berbantuan media audiovisual.

Instrumen yang digunakan dalam penelitian adalah tes unjuk kerja, yaitu tes keterampilan menulis teks prosedur. Sebelum instrumen diujicobakan, langkah awal yang perlu dilakukan adalah menvalidasi instrumen tersebut. Instrumen penelitian ini divalidasi oleh dosen pembimbing yang mengerti dalam bidang evaluasi pembelajaran serta guru mata pelajaran Bahasa Indonesia kelas VII SMP Negeri 12 Padang, yaitu Bapak H. Amril, S.Pd. Selain mendiskusikan instrumen dengan ahlinya, validitas isi instrumen juga dilakukan dengan menyelaraskan instrumen dengan indikator yang digunakan.

\section{Pembahasan}

Dalam bagian ini akan dibahas mengenai hasil keterampilan menulis teks prosedur siswa kelas VII SMP Negeri 12 Padang sebelum dan setelah menggunakan model discovery learning berbantuan media audiovisual sebagai berikut. Pertama, keterampilan menulis teks prosedur sebelum menggunakan model discovery learning berbantuan media audiovisual. Kedua, keterampilan menulis teks prosedur setelah menggunakan model discovery learning berbantuan media audiovisual. Ketiga, pengaruh penggunaan model discovery learning berbantuan media audiovisual terhadap keterampilan menulis teks prosedur siswa kelas VII SMP Negeri 12 Padang. 
Pengaruh Model Discovery Learning Berbantuan Media Audiovisual Terhadap Keterampilan Menulis Teks Prosedur Siswa Kelas VII SMP Negeri 12 Padang-Maretta Arviyana, Syahrul R., Tressyalina

\section{Keterampilan Menulis Teks Prosedur sebelum Menggunakan Model Discovery Learning Berbantuan Media Audiovisual.}

Berdasarkan analisis data yang diperoleh rata-rata hitung keterampilan menulis teks prosedur siswa kelas VII SMP Negeri 12 Padang sebelum menggunakan model discovery learning berbantuan media audiovisual adalah 71,45. Dari rata-rata hitung tersebut dapat disimpulkan bahwa keterampilan menulis teks prosedur siswa kelas VII SMP Negeri 12 Padang sebelum menggunakan model discovery learningberbantuan media audiovisual tergolong Lebih dari Cukup (LdC), pada rentangan (66-75).

Keterampilan menulis teks prosedur siswa kelas VII SMP Negeri 12 Padang sebelum menggunakan model discovery learning berbantuan media audiovisual diklasifikasikan menjadi lima kelompok. Pertama, siswa yang berada pada kualifikasi baik berjumlah 2 orang $(5,88 \%)$, Kedua, siswa yang berada pada kualifikasi baik sekali berjumlah 6 orang $(17,65 \%)$, Ketiga, siswa yang berada pada kualifikasi lebih dari cukup berjumlah 17 orang $(50,00 \%)$, Keempat, siswa yang berada pada kualifikasi cukup berjumlah 7 orang (20,59\%), Kelima, siswa yang berada pada kualifikasi hampir cukup berjumlah 1 orang $(2,94 \%)$.

Keterampilan menulis teks prosedur siswa kelas VII SMP Negeri 12 Padang sebelum menggunakan model discovery learning berbantuan media audiovisual tersebut diperoleh dengan menggunakan tiga indikator sebagai tolak ukurnya. Pertama, mengungkapkan struktur teks prosedur, rata-rata hitung keterampilan menulis teks prosedur siswa kelas VII SMP Negeri 12 Padang sebelum menggunakan model discovery learning berbantuan media audiovisual adalah 79,04. Pemerolehan rata-rata tersebut menggambarkan bahwa pengetahuan siswa tentang struktur teks prosedur sangat dikuasai oleh siswa, selain itu hasil tes unjuk kerja siswa juga menggambarkan bahwa kemampuan siswa sangat dikuasai dalam mengungkapkan strukur teks prosedur. Hal ini sesuai dengan kajian teori yang bersumber dari Feez dan Joyce (dalam Gafur dan Milaningrum, 2015) menjelasakan bahwa teks prosedur menunjukan bagaimana melaksanakan tindakan dalam urutan tertentu. Urutan yang dimaksud adalah sebagai berikut, yaitu (1) tujuan, (2) bahan dan alat, (3) langkah-langkah, dan (4) penutup.

Kedua, ketepatan diksi (pilihan kata), rata-rata hitung keterampilan menulis teks prosedur siswa kelas VII SMP Negeri 12 Padang sebelum menggunakan model discovery learning berbantuan media audiovisual adalah 67,28 . Hal ini menunjukan bahwa siswa kurang terampil menggunakan diksi yang tepat dalam menulis teks prosedur. Hasil tes unjuk kerja siswa juga menggambarkan bahwa siswa belum terampil dalam menggunakan diksi. Keterbatasan dan kurang terampilnya siswa dalam menggunakan diksi akan mempengaruhi teks prosedur yang ditulis siswa. Sesuai dengan pendapat Kridalaksana (2004:35), dalam menyatakan maupun menulis sesuatu didasarkan pada ketepatan diksi yang digunakan. Jadi, dalam menulis teks prosedur ketepatan diksi sangat diperlukan agar teks prosedur tersebut jelas.

Ketiga, ketepatan EBI (Ejaan Bahasa Indonesia), rata-rata hitung keterampilan menulis teks prosedur siswa kelas VII SMP Negeri 12 Padang sebelum menggunakan model discovery learning berbantuan media audiovisual adalah 68,01. Hal ini disebabkan karena kurangnya pemahaman siswa tentang penggunaan ejaan yang kurang tepat. Penggunaan EBI dapat berupa pemakaian huruf kapital, tanda titik, dan tanda koma (Permendikbud, 2015:7-28). Sejalan dengan itu, penggunaan EBI (Ejaan Bahasa Indonesia) dapat mempengaruhi ketepatan kalimat yang ditulis, serta jelas atau tidaknya suatu kalimat dalam teks prosedur juga dipengaruhi oleh ketepatan EBI. Hasil tes ujuk kerja yang ditulis siswa menggambarkan bahwa siswa kurang mampu menggunakan EBI yang tepat.

\section{Keterampilan Menulis Teks Prosedur Setelah Menggunakan Model Discovery Learning Berbantuan Media Audiovisual.}

Berdasarkan analisis data yang diperoleh rata-rata hitung keterampilan menulis teks prosedur siswa kelas VII SMP Negeri 12 Padang setelah menggunakan model discovery learning 
berbantuan media audiovisual adalah 82,42. Dari rata-rata hitung tersebut dapat disimpulkan bahwa keterampilan menulis teks prosedur siswa kelas VII SMP Negeri 12 Padang setelah menggunakan model discovery learning berbantuan media audiovisual tergolong Baik ( B) pada rentangan (76-85).

Keterampilan menulis teks prosedur siswa kelas VII SMP Negeri 12 Padang setelah menggunakan model discovery learning berbantuan media audiovisual diklasifikasikan menjadi sembilan kelompok. Pertama, siswa yang berada pada kualifikasi sempurna berjumlah 3 orang (9,38\%), Kedua, siswa yang berada pada kualifikasi baik sekali berjumlah 10 orang $(31,25 \%)$, Ketiga, siswa yang berada pada kualifikasi baik berjumlah 12 orang (37,51\%), Keempat, siswa yang berada pada kualifikasi lebih dari cukup berjumlah 6 orang (15,63\%), Kelima, siswa yang berada pada kualifikasi cukup berjumlah 1 orang $(3,13 \%)$.

Keenam, siswa yang berapa pada kualifikasi hampir cukup berjumlah 1 orang (3,13\%).

Keterampilan menulis teks prosedur siswa kelas VII SMP Negeri 12 Padang setelah menggunakan model discovery learning berbantuan media audiovisual tersebut diperoleh dengan menggunakan tiga indikator sebagai tolak ukurnya. Pertama, mengungkapkan struktur teks prosedur, rata-rata hitung keterampilan menulis teks prosedur siswa kelas VII SMP Negeri 12 Padang sebelum menggunakan model discovery learning berbantuan media audiovisual adalah 86,72. Hal ini disebabkan dalam pembelajaran menulis teks prosedur setelah menggunakan model discovery learning berbantuan media audiovisual siswa diajarkan membuat teks prosedur dengan cara diberikan sebuah video yang terkait dengan teks prosedur, sehingga siswa dapat menulis teks prosedur berdasarkan video yang diputarkan. Hasil tes unjuk kerja siswa menggambarkan bahwa siswa mampu menulis teks prosedur berdasarkan struktur teks prosedur yaitu tujuan, bahan dan alat, langkah-langkah dan penutup. Hal ini sesuai dengan kajian teori, yaitu dalam mengungkapkan struktur teks prosedur yang harus diperhatikan siswa adalah pada bagian tujuan yang dianggap penting karena pada bagian tujuan tersebut terlihat jelas apa yang ingin siswa buat. Jadi, dengan adanya model discovery learning berbantuan media audiovisual dalam pembelajaran menulis teks prosedur siswa mampu mengembangkan struktur teks prosedur yang sesuai dan relevan dengan media audiovisual yang diberikan.

Kedua, ketepatan diksi (pilihan kata), rata-rata hitung keterampilan menulis teks prosedur siswa kelas VII SMP Negeri 12 Padang setelah menggunakan model discovery learning berbantuan media audiovisual adalah 80,08 . Hal ini disebabkan dalam pembelajaran menulis teks prosedur setelah menggunakan model discovery learning berbantuan media audiovisual siswa diajarkan untuk menggunakan diksi yang tepat yang terdapat dalam teks prosedur. Penggunaan diksi yang tepat mengakibatkan kalimat yang digunakan dalam teks prosedur memiliki makna yang jelas, serta kata-katanya mudah dipahami. Hal ini sesuai dengan pendapat Kridalaksana (2004:35), yaitu siswa yang tepat dalam menggunakan diksi ditandai dengan kejelasan siswa terhadap menyatakan sesuatu dalam satu kalimat. Jadi, berdasarkan nilai-nilai rata-rata yang diperoleh siswa tersebut menggambarkan bahwa siswa mampu menggunakan diksi yang tepat dalam menulis teks prosedur.

Ketiga, ketepatan EBI (Ejaan Bahasa Indonesia), rata-rata hitung keterampilan menulis teks prosedur siswa kelas VII SMP Negeri 12 Padang sebelum menggunakan model discovery learning berbantuan media audiovisual adalah 80,47. Pada indikator ini siswa mampu menulis teks prosedur dengan ejaan yang tepat. Hal ini disebabkan dalam pembelajaran menulis teks prosedur dengan menggunakn model discovery learning berbantuan media audiovisual siswa diajarkan untuk menulis teks prosedur dengan ejaan yang tepat. Sesuai dengan kajian teori, penggunaan EBI dalam menulis teks prosedur dapat berupa pemakaian huruf kapital, tanda titik, dan tanda koma (Premendikbud,2015:7-28). Berdasarkan hasil tes unjuk kerja siswa, siswa memiliki kemampuan dapat menggunakan EBI dengan tepat. Jadi disimpulkan bahwa ada pengaruh model discovery learning berbantuan medai audiovisual terhadap keterampilan menulis teks prosedur tersebut. 
Pengaruh Model Discovery Learning Berbantuan Media Audiovisual Terhadap Keterampilan Menulis Teks Prosedur Siswa Kelas VII SMP Negeri 12 Padang-Maretta Arviyana, Syahrul R., Tressyalina

\section{Pengaruh Model Discovery Learning Berbantuan Media Audiovisual terhadap Keterampilan Menulis Teks Prosedur Siswa Kelas VII SMP Negeri 12 Padang.}

Ditinjau dari hasil tes keterampilan menulis teks prosedur siswa kelas VII SMP Negeri 12 Padang setelah menggunakan model discovery learningberbantuan media audiovisual lebih tinggi dibandingkan sebelum menggunakan model discovery learning berbantuan media audiovisual. Hal ini terbukti dari hasil penelitian yang menunjukan bahwa keterampilan menulis teks prosedur siswa kelas VII SMP Negeri 12 Padang setelah menggunakan model discovery learningsetelah menggunakan model discovery learning berbantuan media audiovisual berada pada kualifikasi Baik ( B) dengan nilai rata-rata 82,42, sedangkan keterampilan menulis teks prosedur siswa kelas VII SMP Negeri 12 Padang sebelum menggunakan model discovery learning berbantuan media audiovisual berada pada kualifikasi Lebih dari Cukup (LdC) dengan nilai ratarata 71,45 . Demikian juga dengan uji hipotesis yang dilakukan $t_{\text {tabel }}=1,70<t_{\text {hitung }}=4,79$ pada taraf signifikansi 95\%.

Berdasarkan hasil analisis, diperoleh gambaran tentang keterampilan menulis teks prosedur siswa kelas VII SMP Negeri 12 Padang sebelum dan setelah menggunakan model discovery learning berbantuan media audiovisual berupa temuan positif dan temuan negatif. Temuan positif ada dua, yaitu (1) siswa kelas VII SMP Negeri 12 Padang belum terampil menulis teks prosedur sebelum menggunakan model discovery learning berbantuan media audiovisual yang dilihat dari indikator struktur teks prosedur, pilihan kata dan ejaan bahasa indonesia, (2) siswa kelas VII SMP Negeri 12 Padang sudah terampil menulis teks prosedur sebelum menggunakan model discovery learning berbantuan media audiovisual yang dilihat dari indikator struktur teks prosedur, diksi dan ejaan bahasa Indonesia. Hal ini dibuktikan dengan rata-rata keterampilan menulis teks prosedur setelah menggunakan model discovery learning berbantuan media audiovisual lebih tinggi dibandingkan sebelum menggunakan model discoverylearning berbantuan media audiovisual. Model discovery learning berbantuan media audiovisual sangat berpengaruh terhadap keterampilan menulis teks prosedur.

Keterampilan menulis teks prosedur siswa kelas VII SMP Negeri 12 Padang sebelum menggunakan model discovery learning berbatuan media audiovisual masih sedang karena berada pada kualifikasi Lebih dari Cukup (LdC) dengan nilai rata-rata 71,45. Faktor tersebut diakibatkan karena siswa belum terbiasa menulis teks prosedur berdasarkan indikator teks prosedur, diksi, dan ejaan bahasa Indonesia, dan tanpa adanya bantuan model dan media pembelajaran, seperti model discovery learning berbantuan media audiovisual. Mereka masih kesulitan mengembangkan ide tulisan dengan bahasa mereka sendiri.

Berdasarkan uraian tersebut, disimpulkan bahwa guru sangat berperan sebagai fasilitator sedangkan siswa harus aktif dalam pembelajaran yang sedang berlangsung. Model pembelajaran kepada siswa agar siswa tidak cepat bosan dalam belajar khususnya menulis teks prosedur adalah dengan menggunakan model discovery learning berbantuan media audiovisual dalam pembelajaran menulis teks prosedur. Perbedaan rata-rata keterampilan menulis teks prosedur sebelum dan setelah menggunakan model discovery learning berbantuan media audiovisual siswa kelas VII SMP Negeri 12 Padang, dianggap sebagai pengaruh yang ditimbulkan oleh penggunaan model discovery learning berbantuan media audiovisual yang diberikan kepada siswa kelas VII SMP Negeri 12 Padang. Dengan demikian, disimpulkan bahwa penggunaan model discovery learning berbantuan media audiovisual sangat berpengaruh secara signifikan terhadap keterampilan menulis teks prosedur siswa kelas VII SMP Negeri 12 Padang.

\section{Simpulan dan Saran}

Berdasarkan penelitian yang telah dilakukan, keterampilan teks prosedur tanpa menggunakanmodeldisocvery learning berbantuan media audiovisual siswakelas VII SMP Negeri 12 Padang berada pada kualifikasi Lebih dari Cukup(LdC) dengan nilai rata-rata 71,45. Nilai ratarata yang diperoleh per indikator, yaitu sebagai berikut. Pertama, indikator I ( Struktur) adalah 79,04. Kedua, indikator II (Diksi) adalah 67.28. Ketiga, indikator III (EBI) adalah 62.50.Keempat, 
indikator IV (EBI) adalah 68,01. Dilihat dari nilai rata-rata tersebut, keterampilan menulis teks prosedur siswakelas VII SMP Negeri12 Padang tanpa menggunakan model discovery learning berbantuan media audiovisual masih rendah.

Keterampilan menulis teks prosedur siswa kelas VII SMP Negeri12 Padang menggunakan model discovery learning berbantuan media audiovisual berada pada kualifikasi Baik (B) dengan nilai rata-rata 82,42. Nilai rata-rata yang diperoleh per indikator, yaitu sebagai berikut. Pertama, indikator I (Struktur) adalah 86.72. Kedua, indikator II (Diksi ) adalah 80.08. Ketiga, indikator III (EBI) adalah 80,47. Dilihat dari nilai rata-rata tersebut, keterampilan menulis teks prosedur siswa kelas VII SMP Negeri12 Padang menggunakan model discovery learning berbantuan media audiovisual sudah berada pada kualifikasi Baik (B).

Berdasarkan uji-t disimpulkan bahwa terdapat pengaruh yang signifikan dalam penggunaan model discovery learning berbantuan media audiovisual terhadap keterampilan menulis teks prosedur siswakelas VII SMP Negeri12 Padang karenat $t_{\text {tabel }}=1,70<\mathrm{t}_{\text {hitung }}=4,79 \mathrm{Jadi}$, disimpulkan bahwa pembelajaran keterampilan menulis teks prosedur siswa kelas VII SMP Negeri 12 Padang dengan menggunakan model discovery learning berbantuan media audiovisual cocok digunakan guru untuk pembelajaran keterampilan menulis teks prosedur.

Berdasarkan kesimpulan yang diperoleh dari hasil penelitian maka dikemukakan saransaran sebagai berikut.Pertama, guru mata pelajaran bahasa Indonesia dalam proses pembelajaran dapat menggunakan model discovery learning berbantuan media audiovisual agar siswa lebih tertarik untuk mengikuti pelajaran sehingga dapat meningkatkan hasil belajar siswa. Kedua, disarankankepadasiswa-siswakelas VII SMP Negeri12 Padang untuk selalu giat dalam menulis terutama menulis teks prosedur.Hal ini dikarenakan menulis dapat melatih berpikir logis sehingga menjadikan siswa yang bersangkutan lebih berani mengungkapkan ide atau gagasannya melalui tulisan. Ketiga, peneliti lain sebagai masukan dan perbandingan dalam melakukan penelitian yang berkaitan dengan masalah ini.

Catatan: artikel ini disusun berdasarkan skripsi penulis dengan pembimbing I, Prof. Dr. Syahrul R., M.Pd.dan Pembimbing II,Dr. Tressyalina, M.Pd.

\section{Daftar Rujukan}

Arifin, Z. (2012). Penelitian Pendidikan: Metode dan Paradigma Baru. Bandung: Remaja Rosdakarya Offset.

As'Adah S.N , Made Sutama, Gede Nurjaya. (2016). "Pembelajaran Menulis Teks Prosedur Berdasarkan Hasil Wawancara di Kelas VIII A1 SMP Negeri 1 Singaraja. http://ejournal pendidikan bahasa dan sastra Indonesia Universitas Pendidikan Ganesha Jurusan Pendidikan Bahasa dan Sastra Indonesia Vol 5 No 3 (di unduh 30 Mei 2016)

Gafur, A dan Milaningrum. E (2015). Penulisan Teks Prosedur yang dinilai MenggunakanPortofolio Kepada Mahasiswa Semester Empat Pada Jurusan Tata Boga diPoliteknik Negeri Balikpapan. (Jurnal Sains Terapan, Vol 1, No 1.(diunduh25 Agustus 2016)

Gina Rosarina, Ali Sudin, Atep Sujana. (2016). "Penerapan Model Discovery Learning Untuk Meningkatkan Hasil Belajar Siswa Pada Materi Perubahan Wujud Benda. http://ejournal Pena ilmiah, Vol 1, No1 (di unduh 3 Agustus 2017)

Kridalaksana, Harimurti. (2008). Kamus Linguistik. Jakarta: PT Gramedia Pustaka Utama.

Pradana, P.G.A, Artawan. G, Darmayanti. M. (2013). "Pembelajaran Menulis Teks Prosedur dengan Metode Discovery Learning di Kelas X MIA 2 SMA Negeri 1 BlahBatuh.http://e-journal Jurusan Pendidikan Bahasa Dan Satra Indonesia, Undiksa Vol : 3 No1 Tahun 2015. 
Pengaruh Model Discovery Learning Berbantuan Media Audiovisual Terhadap Keterampilan Menulis Teks Prosedur Siswa Kelas VII SMP Negeri 12 Padang-Maretta Arviyana, Syahrul R., Tressyalina

(diunduh pada 30 Mei 2017)

Permendikbud. (2015) . Pedoman Umum Ejaan Bahasa Indonesia. Jakarta: Kemendikbud.

Sudjana, nana dan Ibrahim.(2007). PenelitiandanPenilaianPendidikan.Bandung: SinarbaruAlgensindo.

Sugiyono. (2010). Metode Penelitian Kuantitatif, Kualitatif, dan R\&D. Bandung: Alfabeta.

Tumurun. S.W, Gusrayani. D, Jayadinata. (2016) "Pengaruh Model Pembelajaran Discovery Learning TerhadapKeterampilan Berpikir Kreatif Siswa Pada Materi Sifat-SifatCahaya. http:// jurnal Pena Ilmiah Vol 1, No 1 (diunduh 3 Agustus 2017)

Wirnani, Slamet Santosa, Murni Ramli. (2016). "Penerapan Model DiscoveryLearning Untuk Meningkatkan Oral Activities Siswa SMA" http://jurnal BIOEDUKASI 9 (1), 5561(diunduh 4 Agustus 2017) 